\title{
POSITION OF TOURISM IN GLOBAL ECONOMY AND ITS IMPACT ON GDP, EMPLOYMENT AND INVESTMENTS
}

\author{
Predrag Vukadinović \\ Singidunum University, Belgrade \\ Aleksandar Damnjanović and Zoran Jovanović \\ High School of Academic Studies "Dositej”, Belgrade
}

The world has already undergone the globalization process in all segments of the economy. This paper addresses the issue of the ways in which globalization affects tourism as the industry and economic activity. Furthermore, tourism as an economic activity exerts a considerable impact on other activities. Therefore, we have to focus more on the extent and the way this influence is exerted. Also, tourism has an impact on the formation of the gross domestic product, as well as employment and investment. Tourism cannot develop without foreign direct investment, and this paper shows the position of tourism in relation to other activities concerning the number and value of green field investment.

Key Words: tourism, globalization, gross domestic product, employment, foreign direct investment

\section{Introduction}

Global changes have affected almost every segment of social, political, cultural life $\mathcal{J}_{\text {and }}$ the overall economy. They are manifested through neutralization of practically every barrier, which has resulted in liberalization of international trade, competition, free movement of capital and workforce independently of national borders, free movement of investments, etc. As an increasingly important activity, tourism undergoes all of these changes, especially mass tourism, which can be seen in all dimensions of global change. Tourism is an example of the very strong impact of globalization, especially concerning the development of information technology, communications, transport etc. As an example of rapid growth and its increasingly important role in the world market, tourism exerts a significant impact on other related industries, either in indirect or direct manner. The initial idea that tourism is the consequence of economic development has evolved with empirical research into a new idea that tourism is rather becoming an important factor of economic development. Taking that into account, tourism is gradually becoming a strong mover and engine of development for other related industries. Also, tourism is gaining important potential for development, having in mind the fact that this commercial activity connects the sale of goods and services, and its characteristic to bring the consumer to the producer and not vice versa. The influence of tourism can also be seen in creating possibilities for small 
businesses to expand and develop their business activity which, in other conditions, could not breach global supply chains. An increasingly growing economic role and impact of tourism undeniably exerts considerable influence on creation of the gross domestic product (GDP) in both direct and indirect way as the appropriate analysis and display. From the broadest perspective, the direct and indirect impacts of this industry on GDP, employment and investment analyzed through the Travel \& Tourism (T \& T), which includes the application of the methodology, is constructed by the United Nations Statistic Division entitled the Tourism Satellite Account (TSA), which is recommended when it comes to the impact of tourism on the development of economic relations. This activity employs an increasing number of people each year and it also exerts direct or indirect impact on development of not only their own, but other activities, as well. In the context of tourism development, foreign direct investment (FDI) is unavoidable as a factor of growth dynamics, especially the need to use developing countries and economies. Regardless of the importance of FDI as a factor of tourism development, numerous problems occur in the analysis of this field. This happens mostly because tourism is not labeled as formal tourism industry in the classification of national accounts, which means that there is not a trustworthy and single piece of evidence that FDI is directly connected with this industry. This situation creates many methodological issues, having in mind that there is no single methodology for recording FDI in this industry. The initial efforts for outlining a single methodology have been done by forming twelve separate national accounts connected to tourism activities. When analyzing FDI forms, one can observe that mergers, acquisitions and privatization are more common forms of entering foreign markets than green field investments. However, green field investments have an advantage in certain cases having in mind their character and effects on employment, keeping the invested capital, as well as the transfer of new technologies, management, introduction of new kinds of long - term services, etc. Keeping in mind the listed characteristics, green field investments in the hospitality sector have been analyzed (by the classification of UNCTAD), taking into account that tourism does not have full evidence of FDI, as previously mentioned.

\section{Results and Discussion}

This research is based on three elements that are in the focus of this analysis: tourism in relation to globalization, relationship between tourism and economic development and impact of tourism on other industries and FDI in tourism.

\section{Tourism in relation to globalization}

Globalization as a global phenomenon has affected almost every sphere of social life, especially in the post-war period. There are numerous and varied definitions of this concept, which is why the complexity of the concept in both science and literature initiates different approaches necessary for providing its definition.

Global economy, as a specific dimension of globalization has initiated various changes, firstly in the sphere of liberalization of international trade, competition, free movement of capital and workforce, investments, etc. A special characteristic of this 
phenomenon is the removal of barriers for capital, goods, financial and investment flows (Vukadinović et al., 2013). One of the most important economic activities in the process of globalization is tourism. This view is especially related to mass tourism which is considered to be one of the visible manifestations of globalization, so that tourism development can be seen in every dimension of these processes: economic, social, cultural and even political one (Halowiecka et al., 2011). On the basis of huge significance of tourism in the worldwide economy, the same authors stress the importance and popularity of researching these relations, particularly in connection with economic dependence between tourism and globalization at a global or regional level. In both research and theory, tourism stands out as an example of a very strong influence of globalization. Progress and transfer of technology, efficient transportation of travelers, open borders, etc. are some of the important characteristics of globalization impact on tourism development. Certain authors (Pantelescu \& State, 2008) assert that tourism is one of the examples of globalization that is the most visible because people are given the chance to spend their free time comfortably. Also, many companies e have the fundamental experience of globalization. Air traffic is growing exponentially (the time it takes to get to the destination is shorter, which leads to more time spent at a tourist location itself), borders have opened, as well as free markets. Globalization has opened new possibilities for tourism development through development of electronic technology, communications and transport. The Internet, fast communication and smaller costs of air travel are becoming more important every day. The Internet has drastically lowered costs by reducing the importance of intermediaries or excluding them all together, and it has also become one of the most sought ones after perks of comfortable accommodation. In general, a large number of authors agree with the fact that globalization has increased the interdependence of economies, countries and people. This interdependence does not only include mega companies, but it also includes small and medium-sized enterprises, as well as family businesses. The process of globalization has affected the creation and functioning of the global tourism market, which demands competition on an equal basis regardless of the country of origin. Finally, globalization has opened completely new possibilities for the overall development and the development of tourism market. One can say that globalization plays a crucial role in the growth of international tourism in the world market. The contribution of globalization in economic, political and cultural terms also reflects on the evolution of tourism in the context of increase of travels both inside and outside borders. Globalization, openness of borders, growth of all types of transport, especially air traffic, appearance of the Internet and increase in the number of people who can afford to take vacation and travel outside the national borders, have all influenced the strengthening of international tourism over national one (Nedeljković et al., 2013).

\section{Tourism and economic development-impact of tourism on other areas of economy}

The history of the importance of tourism for economic development and its impact on the development of other economic areas ranges from views that tourism is a consequence of economic development to the current position that tourism is a factor of economic development. According to Bošković (2009), it has long been widely accepted that tourism is a con- 
sequential phenomenon of economic development, which is based on the premise that tourism could have an impact on economic development, but with a previously achieved certain level of economic development. This view is based on the notion that the most significant factors driving the development of tourism are also primarily the results of economic development. However, later studies have pointed out that tourism makes an impact on other economic activities, which have in fact established tourism as one of the factors of economic development. In the context of globalization, international tourism continues to strengthen its role in relation to national tourism. Given the ever-growing importance of international tourism, Table 1 shows the indicators of international tourism development.

Table 1 - Development of international tourism - quantitative indicators

\begin{tabular}{|c|c|c|c|c|c|c|c|c|c|c|c|}
\hline \multirow[b]{2}{*}{ Year } & \multirow[b]{2}{*}{1990} & \multicolumn{5}{|c|}{$\begin{array}{l}\text { International Tourist Arrivals } \\
\text { (in millions) }\end{array}$} & \multirow{3}{*}{$\begin{array}{c}\begin{array}{c}\text { Market } \\
\text { share } \\
(\%)\end{array} \\
2014^{*} \\
100\end{array}$} & \multicolumn{3}{|c|}{$\begin{array}{l}\text { Change in growth } \\
(\%)\end{array}$} & \multirow[t]{2}{*}{$\begin{array}{c}\text { Yearly } \\
\text { percent. } \\
(\%)\end{array}$} \\
\hline & & 19952000 & 2005 & 2010 & 2013 & 2014 & & $12 / 11$ & $113 / 1$ & $214 * / 13$ & \\
\hline World & 435 & $527 \quad 674$ & 809 & 949 & 1,087 & 1,133 & & 4.2 & 4.6 & 4.3 & 3.8 \\
\hline $\begin{array}{l}\text { Developed } \\
\text { economies }\end{array}$ & 296 & $336 \quad 420$ & 466 & 513 & 586 & 619 & 54.7 & 4.0 & 4.7 & 5.8 & 3.2 \\
\hline $\begin{array}{l}\text { Developing } \\
\text { economies }\end{array}$ & 139 & $191 \quad 253$ & 343 & 435 & 501 & 513 & 45.3 & 4.4 & 4.5 & 2.4 & 4.6 \\
\hline \multicolumn{12}{|l|}{$\begin{array}{l}\text { Regions by } \\
\text { UNWTO: }\end{array}$} \\
\hline Europe & 261.5 & 304.7386 .4 & 453.0 & 488.95 & 566.4 & 581.8 & 51.4 & 3.9 & 4.9 & 2.7 & 2.8 \\
\hline $\begin{array}{l}\text { Asia and the } \\
\text { Pacific }\end{array}$ & $55.8 \varepsilon$ & 82.1110 .3 & 154.0 & 205.4 & 249.8 & 263.3 & 23.2 & 6.9 & 6.8 & 5.4 & 6.1 \\
\hline America & 92.81 & 109.1128 .2 & 133.3 & 150.1 & 167.5 & 181.0 & 16.0 & 4.5 & 3.1 & 8.0 & 3.5 \\
\hline Africa & 14.7 & $18.7 \quad 26.2$ & 34.8 & 49.5 & 54.4 & 55.7 & 4.9 & 4.8 & 4.7 & 2.4 & 5.4 \\
\hline Middle East & 9.6 & $12.7 \quad 22.4$ & 33.7 & 54.7 & 48.4 & 51.0 & 4.5 & -5.3 & -3.1 & 5.4 & 4.7 \\
\hline
\end{tabular}

Source: World Tourism Organization (UNWTO), Tourism Highlights edition 2015, Data as collected by UNWTO May 2015. pp.4.

Globally, tourism has exhibited a steady increase in the number of tourists in the last 24 years (analyzed for the period 1990-2014). In 1990, the recorded number of tourists was 435 million, reaching 1,133 million tourists by 2014 , i.e. 2.6 times more than in 1990 . This trend is also present in developed economies, where the number of tourists rose from 296 million in 1990 to 619 million, or 2.09 times. In developing economies, this number grew from 139 million tourists in 1990 to 513 million in 2014, or fantastic 4.7 times.

The growth in the number of tourists at a regional level is also constant. Europe has recorded growth in the number of tourists from 261.5 million in 1990 to 581.8 million in 2014, or 2.22 times. Asia and the Pacific are becoming increasingly important tourist destinations, as the number of tourists rose from 55.8 million in 1990 to 263.3 million in 2014, or 4.72 times. America also recorded an increased number of tourists from 92.8 million in 1990 to 181 million in 2014 , or 1.95 times. Africa is rapidly progressing towards becoming an interesting tourist destination with the number of tourists growing from 14.7 million in 1990 to 
Position of Tourism in Global Economy and its Impact on GDP, Employment and Investments

55.7 million in 2014 or 3.78 times. The Middle East also follows the growth trend in the number of tourists, as their number increased from 9.6 million in 1990 to 51 million in 2014, or 5.31 times, which is also the largest regional increase in the number of tourists.

The analysis of the growth rate in the number of tourists in 2014 compared to 2013shows that the achieved growth rate at a global level was 4.3\%, developed economies achieved a growth rate of $5.8 \%$, while developing economies recorded a growth rate of $2.4 \%$. At the regional level, the highest growth rate was achieved by America- $8 \%$, followed by Asia, the Pacific and the Middle East with a growth rate of $5.4 \%$, then Europe with $2.7 \%$ and Africa with $2.4 \%$.

The highest average annual growth rate in the analyzed period (1990-2014) was observed in Asia and the Pacific with a growth rate of $6.1 \%$, indicating the growing attractiveness of tourist destinations in the region, followed by Africa with $5.4 \%$, Middle East with $4.7 \%$ and Europe with 2.8\%. Developed countries had an average annual growth rate of $3.2 \%$ in the number of tourists, while developing economies recorded an average annual growth rate of $4.6 \%$. The global average annual growth rate in the number of tourists was $3.8 \%$.

In addition to these quantitative indicators, financial indicators also point to the intense tourism development, as shown in Table 2.

Table 2 - Development of international tourist-financial indicators

\begin{tabular}{|c|c|c|c|c|c|c|c|c|}
\hline \multirow[b]{2}{*}{ Year } & \multicolumn{4}{|c|}{$\begin{array}{l}\text { International tourism } \\
\text { revenues ( } \% \text { of change) }\end{array}$} & \multicolumn{2}{|l|}{$\begin{array}{c}\text { Market } \\
\text { Share (\%) }\end{array}$} & \multicolumn{2}{|c|}{$\begin{array}{l}\text { Revenues (USD) } \\
\text { (billion) per tourist }\end{array}$} \\
\hline & $11 / 10$ & $12 / 11$ & $13 / 1$ & $14^{*} / 13$ & $2014^{*}$ & 2013 & $2014^{*}$ & $2014^{*}$ \\
\hline World & 4.6 & 3.9 & 5.1 & 3.7 & 100 & 1,197 & 1,245 & 1,100 \\
\hline $\begin{array}{l}\text { Developed } \\
\text { economies }\end{array}$ & 5.8 & 3.7 & 5.7 & 3.2 & 65.5 & 784 & 815 & 1,320 \\
\hline $\begin{array}{l}\text { Developing } \\
\text { economies } \\
\text { Regions by } \\
\text { UNWTO: }\end{array}$ & 2.5 & 4.4 & 4.0 & 4.6 & 34.5 & 413 & 430 & 840 \\
\hline Europe & 5.0 & 1.9 & 4.2 & 3.6 & 40.9 & 491.7 & 508.9 & 870 \\
\hline $\begin{array}{l}\text { Asia and } \\
\text { the Pacific }\end{array}$ & 8.6 & 6.7 & 8.6 & 4.1 & 30.3 & 360.7 & 376.8 & 1,430 \\
\hline America & 4.6 & 4.7 & 4.7 & 3.1 & 22.0 & 264.2 & 274.0 & 1,510 \\
\hline Africa & 2.3 & 6.0 & 2.6 & 2.9 & 2.9 & 35.5 & 36.4 & 650 \\
\hline Middle East & -15.6 & 0.9 & -6.9 & 5.7 & 4.0 & 45.2 & 49.3 & 970 \\
\hline
\end{tabular}

Source: World Tourism Organization (UNWTO), Tourism Highlights edition 2015, Data as collected by UNWTO May 2015. pp. 5.

At a global level, international tourism revenues have grown from 1,197 billion USD to 1,245 billion USD, which shows a growth rate of $3.7 \%$. This kind of growth was also recorded in developed economies, where revenues rose from 784 billion USD in 2013 to 815 billion USD in 2014 , or by $3.2 \%$. In developing economies, revenues rose from 413 billion USD in 2013 to 430 billion USD in 2014, or by $4.6 \%$. Revenue growth has also been recorded at a regional level. Europe had the biggest revenue growth, where revenues amounted to 17.2 billion USD, which shows the growth of $3.6 \%$, whilst the smallest growth was observed in Africa and amounted to 0.9 million USD, or by $2.9 \%$. 
The effects of tourism on the overall economic development, i.e. the economic effects of tourism can be treated as direct and indirect. The direct effects of tourism on the overall economy can be viewed through a few of the most important effects: effects on the national product and income, development of economic industries related to tourism sector, balance of payments, population and employment, investments and effects on insufficiently developed areas and countries. The indirect effect is related to industries that usually follow the tourism activities, primarily agriculture, industry and construction (Bošković, 2009). The tourism effects on other economic activities are presented in Figure 1.

Box figure 1. Tourism value chain

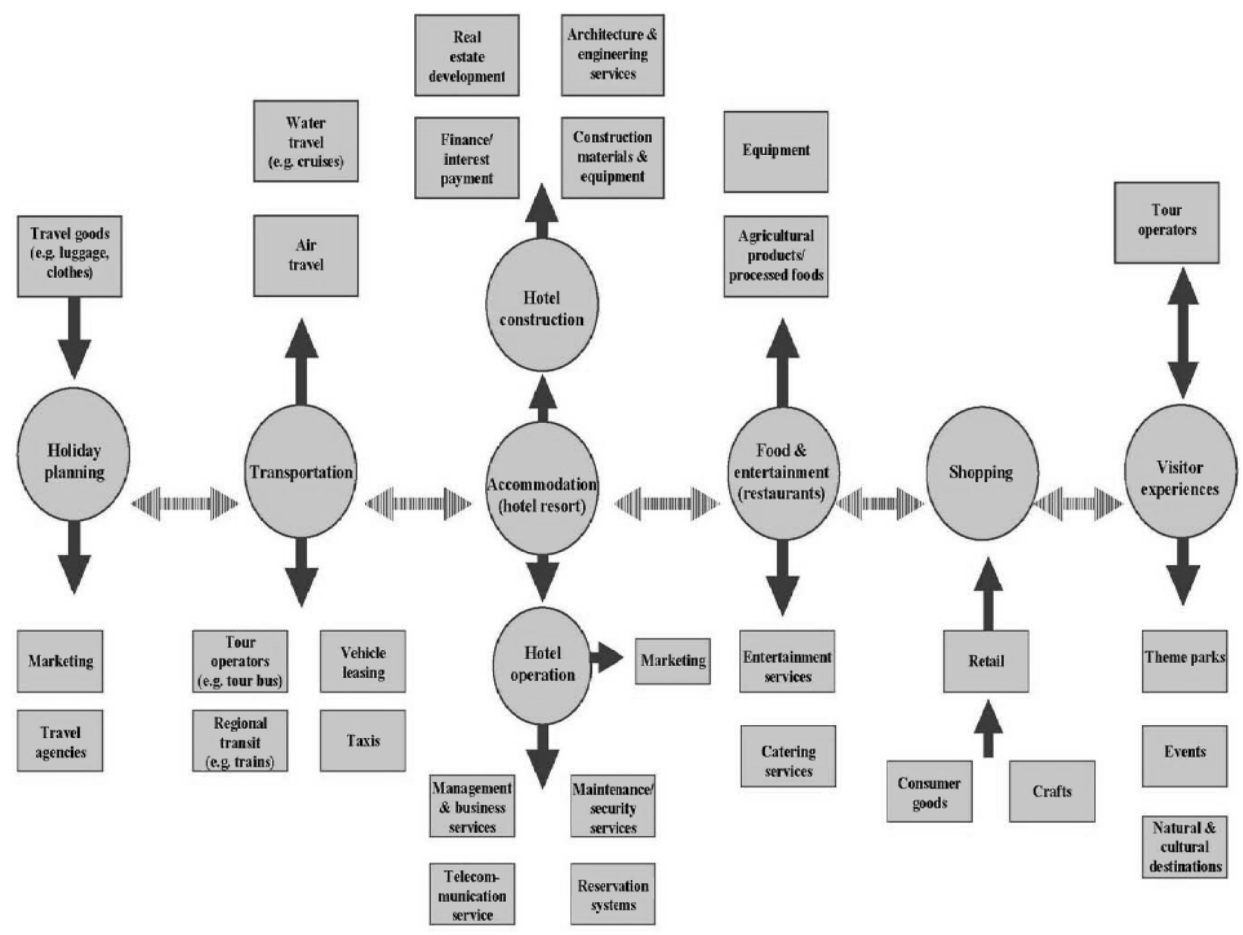

Figure 1 - The influence of tourism industry on other service industries and production

Source: Gollub et al. (2003), FDI in Tourism: The Development Dimension, UNITED NATIONS, New York and Geneva, 2007, p. 3.

Tourism possesses the important development potential. This stems from the fact that tourism cross - connects both sales of goods and services, such as accommodation, transport, entertainment, sale of agricultural products, etc. An important fact is that tourism enables the consumer to come to the producer and not the other way round, so that even the smallest transaction becomes a part of the global economy. Every sale of goods or services to foreign tourists has a significant positive effect on small businesses, 
Position of Tourism in Global Economy and its Impact on GDP, Employment and Investments

which otherwise could not breach the global supply chains (UNCTAD, 2007). Apart from direct and indirect effects on the economy, it is also important to show the possible positive and negative effects that can be seen in multiple elements, as displayed in Table 3:

Table 3 - Possible effects of tourism

\begin{tabular}{|c|c|}
\hline POSITIVE EFFECTS & NEGATIVE EFFECTS \\
\hline Increase of revenues/increase of living standard & Big dependence on tourism \\
\hline Employment opportunities & Increased living costs-accommodation, food and services \\
\hline Improvement of infrastructure in tourism & Pollution and traffic congestion \\
\hline Increase of tax income & $\mathrm{TNC}^{*}$ dominate the tourism market \\
\hline $\begin{array}{l}\text { Raising awareness and increasing resources } \\
\text { for cultural and natural heritage }\end{array}$ & Harmful effects on cultural and natural heritage \\
\hline Capital inflows & $\begin{array}{l}\text { Sensitivity of business cycles and changes of } \\
\text { business attitude }\end{array}$ \\
\hline Transfer of professionalism and managerial skills & Little control of tourism development \\
\hline Market connections & Unacceptable form and volume of development \\
\hline Visible effects for local entrepreneurs & Invasion of open spaces \\
\hline
\end{tabular}

*TNC - Trans National Companies

Source: UNCTAD (2010), expanding on UNESCAP (2001) and on Kusluva S and Karamustafa K (2001).

\section{Direct, indirect and total impact of tourism ( $T \& T)$ on GDP, employment and investment}

From the widest standpoint tourism as T \& T performs direct, indirect and total impact on both national economy and global economy. As shown in Figure 1, the TSA model is based on the following:

\section{DIRECT \\ Travel \& Tourism contribution \\ COMMODITIES \\ - Accommodation \\ - Transportation \\ - Entertainment \\ - Attractions \\ INDUSTRIES \\ - Accommodation services \\ - Food \& beverage services \\ - Retail Trade \\ - Transportation services \\ - Cultural, sports \& recreational services \\ SOURCES OF SPENDING \\ - Residents national T \& T spending \\ - Businesses national travel spending \\ - Visitor exports \\ - Individual government T \& T spending}

\begin{tabular}{|l|l|l|}
\hline INDIRECT & \begin{tabular}{|l|l|} 
INDUCED \\
Travel \& Tour- \\
ism contribution \\
- T \& T invest- \\
ment spending \\
-Government \\
collective T \& T \\
spending \\
- Impact of pur- \\
chases from \\
suppliers
\end{tabular} & $\begin{array}{l}\text { Tourism } \\
\text { contribution } \\
\text { spending of } \\
\text { direct and } \\
\text { indirect em- } \\
\text { ployees } \\
\text { - Food and } \\
\text { beverages } \\
\text { - Recreation } \\
\text { - Clothing } \\
\text { - Housing } \\
\text {. . . }\end{array}$ \\
\hline
\end{tabular}


Direct, indirect and total impact on GDP, employment and investment provides a more complete picture of the impact of $T \&$ on other activities and industries because TSA model takes into account all created values, employment and investments that are in any of these ways connected with tourism activities. The figure clearly shows a large number of services and industries related to tourism and that tourism also greatly affects them.

\section{$T \& T$ Impact on GDP}

However, according to statistical indicators, the global economic crisis induced in 2008 resulted in variable motion of GDP growth rate worldwide. The sudden fall in GDP was recorded in 2011 compared to 2010 , from $4.09 \%$ to $2.80 \%$ and further to $2.18 \%$ in 2012. However, from 2012 to 2014, GDP growth is not spectacular, but still notable as optimistic, bearing in mind all the global economic problems, as well as the number of national economies in which there was a decrease of GDP in this period, while a number of national economies started recovering. Since 2012 the growth of GDP was recorded by $2.18 \%$ per annum to $2.48 \%$ in 2014 . The activity of T \& T follows this GDP growth, but it can be seen that the growth of T \& $T$ is slightly faster than indicated by GDP growth rates. This ratio indicates that $T \& T$ is one of the groups of industry that exerts a more significant impact on GDP growth, as shown in Table 4.

Table 4 - T \&T Impact on GDP (in billion US dollars)

\begin{tabular}{|c|c|c|c|c|c|}
\hline & 2010 & 2011 & 2012 & 2013 & 2014 \\
\hline 1. Gross domestic product-world* & 65.430 & 72.443 & 73.699 & 75.641 & 77.451 \\
\hline $\begin{array}{l}\text { 1.2. Growth rates of GDP per } \\
\text { year } \\
\text { 2. Direct contribution }\end{array}$ & 4,09 & 2,80 & 2,18 & 2,28 & 2,48 \\
\hline of Travel \& Tourism to GDP** & 2.058 & 2.132 & 2.210 & 2.285 & 2.365 \\
\hline 2.1. $\%$ of whole economy GDP & 3,15 & 2,94 & 3,00 & 3,02 & 3,05 \\
\hline $\begin{array}{l}\text { 2.2. Growth Direct contribution } \\
\text { of Travel \& Tourism } \\
\text { 3. Total contribution } \\
\text { of Travel \& Tourism }\end{array}$ & 2,20 & 3,60 & 3,70 & 3,40 & 3,50 \\
\hline of whole economy GDP** & 6.567 & 6.846 & 7.083 & 7.316 & 7.581 \\
\hline 3.1. $\%$ of whole economy GDP & 10,04 & 9,45 & 9,61 & 9,67 & 9,79 \\
\hline $\begin{array}{l}\text { 3.2. Growth Total contribution of } \\
\text { Travel \& Tourism }\end{array}$ & 1,30 & 4,30 & 3,50 & 3,30 & 3,60 \\
\hline
\end{tabular}

Source: *GDP: UNCTAD STATISTICS, **Direct and Total Contribution T \& T: World Travel \& Tourism Council, Travel \& Tourism-Economic Impact 2015, World, annual Report.

The analysis of direct contribution of T \& T to GDP growth reveals a slight increase in the nominal value of the amount for the entire analyzed period 2010-2014. The realizable value increased by 2.058 billion US dollars in 2010 to 2.365 billion US dollars in 2014 . Bearing in mind that in the same period the nominal value of GDP recorded growth, a rele- 
vant indicator of growth and constant influence on GDP growth is the percentage of participation of realizable values and growth rates of $T \& T$ in the period analyzed in relation to GDP. However, regardless of the nominal growth of average value of T \& T in $2011 \mathrm{com}$ pared to 2012, growth rates in the past two years indicate the impact of the global economic crisis in T \& T, as the rate of participation of this sector in GDP fell from $3.15 \%$ in 2010 to 2.94 in 2011 . However, the recovery of $T \&$ T activities is evident in the upcoming period, i.e. in the period 2011-2014, during which the percentage share of this activity grew continuously from $2.94 \%$ in 2011 to $3.05 \%$ in 2014 (3.00\% in 2012, 3.02\% in 2013). It cannot be said that this growth is spectacular, as you could not have expected this, taking into account the prolonged effects of the global economic crisis and a drop in purchasing power. However, the growth rate is still stable, which indicates that $T \& T$ as the industry found a solution to prevent the recession, which began with a decline in the share of this sector in 2010 compared to 2011 . With 2.20 in 2010, the growth rate of T \& T direct impact increased to as much as 3.60 in 2011 . This sudden increase has not kept the same growth rate in the coming period, because in 2012 the growth rate rose to 3.70 followed by an evident decline to 3.40 in 2012 and a slight rise in 2014 to 3.50 . This was triggered by relatively stable growth rates in the structure of T \& T direct impact on GDP.

The total impact of $T \& T$ (including direct and indirect impacts using TSA models) in nominal terms shows steady growth from year to year during the analyzed period. Nominal growth of realizable value of T \& T with 6.567 billion US dollars in 2010 reached the level of 7.581 billion US dollars in 2014 , which represents a jump of as much as $19.55 \%$. The total impact of T \& T in GDP, as measured by percentage share in GDP, firstly decreased in participation or impact on GDP from $10.04 \%$ in 2010 to $9.45 \%$ in 2011 . The continued growth in the share of the total impact of T \& T in GDP is evident after the fall in 2011, so that the participation increased in 2012 at $9.61 \%, 2013$ percentage participation grew at $9.67 \%$, to the highest level of participation - the impact of T \& T was manifested in 2014 in the amount of $9.79 \%$. Such trend, nominal and percentage of total-impact of T \& T to GDP, indicate that the industry has a stable effect and growth and thus a stable and growing impact on GDP. The analysis of the growth rate of the total impact shows that exactly the same rule is observed when it comes to direct impact. The growth rate of 1.30 in 2010 increased to 4.30. However, the decline in the growth rate of this sector at 3.50 was observed in 2012, and in 2013 it amounted to 3.30 . The industry experienced the recovery in 2014, when the growth rate reached a level of 3.60 , which is higher than in the previous year.

\section{Impact of $T \&$ T employment on the overall employment}

One of the most negative effects of the global economic crisis is related to employment and job creation. The consequence of the economic crisis is jobs reduction or downsizing. National economies that have managed to find a solution to combat and mitigate the effects of the global economic crisis or greatly reduce its adverse effects managed and preserved jobs and the number of employees. Moreover, some national economies have succeeded in presenting and increasing the number of jobs since 2008 , or to be on the road to recovery, by increasing the number of jobs to be reduced in the first wave of the global economic crisis. 
Globally, the statistics (UNCTAD statistics) show that during the analyzed period the number of employees worldwide increased from 3,236,325 in 2010 to 3,282,415 in 2011. In 2012 , that number rose to $3,328,256$ and $3,373,455$ in 2013 , reaching its peak of $3,417,573$ employees in 2014. Such trend indicates a slight recovery of the economy at the global level, bearing in mind that this increase in the number of employees is not that spectacular, but the increase in the number of jobs or the number of employees gives grounds for optimism that there is a slight recovery and possibility for overcoming the crisis. One should not expect quick and spectacular solutions because this is a process. (Table 5).

Table 5 - Impact of T \& T employment on the overall economy employment (in thousands)

\begin{tabular}{lrrrrr}
\hline & 2010 & 2011 & 2012 & 2013 & 2014 \\
\hline $\begin{array}{l}\text { 1. Total labor force and agriculture labor force } \\
\text { 1.1. Growth of total labor force and agriculture }\end{array}$ & $1.236,325$ & $3,282,415$ & $3,328,256$ & $3,373,445$ & $3,417,573$ \\
labor force & & 1.42 & 1.40 & 1.36 & 1.31 \\
$\begin{array}{l}\text { 2. Direct contribution of Travel \& Tourism to } \\
\text { employment }\end{array}$ & 98,192 & 99,558 & 101,486 & 103,297 & 105,408 \\
$\begin{array}{l}\text { 2.1. Growth of direct force and agriculture labor } \\
\text { force }\end{array}$ & 0.4 & 1.39 & 1.94 & 1.78 & 2.04 \\
$\begin{array}{l}\text { 2.2. \% of the overall economy employment } \\
\begin{array}{l}\text { 3. Total contribution of Travel \& Tourism to } \\
\text { employment }\end{array}\end{array}$ & 3.03 & 3.03 & 3.05 & 3.06 & 3.08 \\
$\begin{array}{l}\text { 3.1. Growth of total labor force and agriculture } \\
\text { labor force }\end{array}$ & -1.30 & 2.17 & 1.99 & 2.09 & 2.26 \\
3.2. \% of the entire economy employment & 7.86 & 7.92 & 7.97 & 8.03 & 8.1 \\
\hline
\end{tabular}

Source: *Total labor force: UNCTAD STATISTICS, ${ }^{*}$ Direct and Total Contribution T \& T: World Travel \& Tourism Council, Travel \& Tourism-Economic Impact 2015, World, annual Report.

The analysis of employment rates in tourism industry, and the number of employees follow the global trend of employment growth. This increase is not insignificant bearing in mind that these activities are classified in the services sector, which is characterized as a laborintensive sector, and it does not employ a large number of people, as is the case with the secondary-manufacturing sector. It is encouraging that the direct impact of $T$ \& $T$ number of employees grew each year of the observed period in this activity from 98,192 thousand employees in 2010 to 99,558 thousand in 2011, 101,486 thousand in 2012, 103,297 thousand in 2013 to the maximum of 105,408 thousand employees in 2014. It is characteristic that since 2012 we undertook the employment in T \& T activities as noticeable on the basis of an analysis of the nominal number of employees. Employment growth in $T \& T$ supports this thesis given that by 2012 this rate was growing faster than the employment rate at the global level, which is noticeable because the growth rate in T \& T increased in 2012 to 1.94, in 2013 to 1.78, in 2014 to 2.04, while globally we observed slower employment growth rates - in 2012 at 1.40 , in 2013 at 1.36 whereas in 2014 it fell to 1.31, while the growth rate in the same year in T \& T advanced to 2.04 . The analysis of the employment growth rate at the global level and $T$ \& $T$ indicates faster employment growth in $T$ \& $T$ than at the global level, which shows that this industry $(T \& T)$ has developed more actively than at the global level. 
Position of Tourism in Global Economy and its Impact on GDP, Employment and Investments

The analysis of the total impact of unemployment on the global employment is better maintained than the growing influence of this industry on the global employment. The number of employees in nominal terms increased each year during the analyzed period, with 254,477 thousand employees in 2010 to 259,996 thousand in 2011, then 265,169 thousand in 2012 to 270,723 employees in 2013 , reaching 276,845 employees in 2014 , which is the largest annual increase in the number of employees. The employee growth rates indicate that after a negative rate of -1.3 in 2010, a sharp increase of 2.17 was observed in 2011, followed by a decline in the employment rate in 2012 to 1.99 . After 2012 the analysis shows continuous employment growth, as well as in 2013 and 2014, to 2.09 and 2.26, respectively. Such growth rates are optimistic and favorable provided that they continue. The total impact of $T \& T$ on the global employment is constantly growing, as demonstrated by the analysis of the growth of participation in employment in the total number of employees globally. The share has been growing continuously since 2010 from $7.86 \%$ to $7.92 \%$ in 2011 , then to $7.97 \%$ in 2012 . Such growing tendency continued in 2013 to $8.03 \%$, while the share of this activity by the number of employees in the global number of employees amounted to $8.10 \%$ in 2014 .

\section{Impact of $T$ \& T on Foreign Direct Investment}

Participation in impact of T \& T investment is analyzed as the impact on FDI (Foreign Direct Investment) using the data from the TSA United Nations statistic division model to cover not only investments in hotels and restaurants, but also investment in other industries that are directly or indirectly related to $T \& T$. In this way, it is possible to realistically show the impact of all investments that have to do with tourism in the aforementioned manner. This analysis is presented in Table 6.

Table 6 - Impact of T \& T investment on Foreign Direct Investment (million US dollars)

\begin{tabular}{lrrrrr}
\hline & 2010 & 2011 & 2012 & 2013 & 2014 \\
\hline 1. Foreign direct investment & $1,328,215$ & $1,564,935$ & $1,403,115$ & $1,467,149$ & $1,228,283$ \\
1.1.Growth Foreign direct investment & 11.94 & 17.82 & -10.34 & 4.56 & -16.28 \\
2. Capital investment in Travel \& Tourism & 718,000 & 740,000 & 767,000 & 784,000 & 814,000 \\
2.1. Growth Capital investment in Travel & & & & & \\
\& Tourism & -4.80 & 3.06 & 3.65 & 2.22 & 3.83 \\
2.2. \% of whole Foreign Direct Investment & 54.06 & 47.29 & 54.66 & 53.44 & 66.27 \\
\hline
\end{tabular}

Source: *Total labor force: UNCTAD STATISTICS, ${ }^{* *}$ Direct and Total Contribution T \& $T^{* *}$ : World Travel \& Tourism Council, Travel \& Tourism-Economic Impact 2015, World, annual Report, *** Capital investment - includes capital investment spending by all industries directly involved in Travel \& Tourism. This also constitutes investment spending by other industries on specific tourism assets such as new visitor accommodation and passenger transport equipment, as well as restaurants and leisure facilities for specific tourism use. This is consistent with the total tourism gross fixed capital formation in Table 8 of the TSA: RMF 2008 (World Travel \& Tourism Council, Travel \& Tourism-Economic Impact 2015, World, annual Report, pp.15).

${ }^{1}$ United Nations, 2008, Tourism Satellite Account: Recommended Methodological Framework, Table No. 8, pp. 66, Statistic Division, New York. 
By analyzing FDI movement, fluctuation of rise and decline of this investment is clearly noticeable. Following an increase of $11.94 \%$ in 2011 and $17.82 \%$ in 2012, a sharp decrease by $10.34 \%$ was observed. Short recovery occurred in 2013 with a growth of $4.56 \%$ followed again by a decrease of $16.28 \%$ in 2014. According to the UN WIR 2015, this fall of investment was due to the instability of the global economy, political uncertainty and geopolitical risk as the most important factors of falling investment. The movement of investments in $T$ \& $T$ points to a completely different situation. The analysis of investment in this industry (T \& T) shows a steady and continuous growth of investment each year of the analyzed period. This growth is manifested by a continuous increase in investments starting from 2010 with 718,000 million US dollars to 740,000 million US dollars in 2011, 767.000 million US dollars in 2012, 784.000 million US dollars in 2013 to the maximum investment reached in 2014 at the amount of 814.000 million US dollars. Growth rates of investments in $T$ \& $T$ point to the stable growth, as the negative growth rates in 2010 by $4.80 \%$ were followed by rapid growth of investment in this industry in 2011 by $3.06 \%$.

This continued in 2012 with the growth rate of $3.65 \%$, while a fall in the growth rate by $2.22 \%$ was observed in 2013 primarily due to higher investment growth at the global level than in T \& T. However, the growth rate of investment in T \& T in 2014 was $3.83 \%$, while there was the already mentioned decline of investment on a global scale. This growing tendency observed in nominal amounts and growth rates shows that the tourism industry is more interesting for investment. This statement indicates and analyzes the share of tourism investment in the amount of investments globally. In 2010, the share of investments in T \& T amounted to $54.06 \%$, while a decline in the participation by $47.29 \%$ was observed in 2011 , and it increased again in 2012 to $54.66 \%$. The circular movement of participation measured by percentage fall in 2013 was $53.44 \%$, but a sudden increase in participation by $66.27 \%$ was observed in 2014. Such a high share of investment in T \& T in relation to the global amount of investment is the result of the TSA model application, which has already been mentioned and includes investments that are directly or indirectly connected to tourism activity on the respective schemes-pictures shown. If we take into account only investment in hotels and restaurants, they would be far less and unrealistic as the indicator takes into account just the direct connection with tourism and indirect connection with other services and industries. Therefore, the TSA model designed by the UN Statistic Division is used to show more realistically tourism impact by investing in this industry in total and the global investment flows.

\section{Foreign direct investment in tourism}

Foreign direct investment (FDI) is the factor of growth dynamics that should be principally used by developing countries i.e. developing economies. However, there are an insufficient number of empirical analyses in this field, keeping in mind the small number of empirical indicators showing the effects of FDI on tourism development in the global economy (UNCTAD, 2007). The main research problem is the fact that tourism is not considered to be the formal tourism industry in the classification of the national accounts. The complexity of tourism as industry and absence of a single methodology for recording FDI in tourism creates methodological problems, meaning that, for example, FDI in hotels and catering facilities can be found under "real estate", FDI in transport is presented as "transport, communications and warehousing", which generally imposes great issues in FDI quantification in tourism, especially concerning properties, revenues or employment. However, in recent times (WTO 2004, pp. 13-14) and with 
Position of Tourism in Global Economy and its Impact on GDP, Employment and Investments

the approval of the statistical commission of the United Nations (2000), new methodological framework has been recommended, which includes twelve separate national accounts related to tourism activities. This methodology includes companies that are directly incorporated into the production and consumption of tourism services and indirectly incorporated companies. Research conducted by the UNCTAD shows these twelve activities that can be assumed to be typical for tourism activities in both direct and indirect way through the TSA model (Tourism Satellite Account), wherein an indicator of FDI frequency in these activities is formed. The model presents the most common TSA frequencies: hotels and similar structures, restaurants and "second homes", occasional FDI frequencies related to transport of travelers and rent of goods and services of railway transport, and scarce FDI frequencies in air traffic services, waterway transport, services that are in the function of traveler transport, tourist agencies, cultural services, sports and other recreational services. With respect to FDI forms, we can conclude that mergers and acquisitions are more common forms of FDI for entering foreign markets as it is more efficient and simple to buy the existing distribution network rather than start business from scratch, which is the characteristic of green field investments, and that is why they are not that widespread as mergers and acquisitions (M\&A), (UNCTAD, 2010).

Foreign companies will invest in international markets if the following three terms are simultaneously met:

1) Ownership: the company has to have ownership as an advantage to be able to efficiently compete with the local companies;

2) Location: companies use the advantages of relocating to the foreign country (big land areas, cheap workforce, rich cultural heritage and a pleasant climate;

3) Internationalization: the company benefits because it directly controls the business activity rather than relying on the services of the local company;

This principle is otherwise known as the "OLI" principle (ownership, location, internationalization).

The analysis of the number and value of green field investments has been performed based on the facts shown in Table 7 and 8 (M\&A), (UNCTAD, 2015).

Table 7 - Number of green field projects by industries, 2010-2014

\begin{tabular}{lrrrrr}
\hline & 2010 & 2011 & 2012 & 2013 & 2014 \\
\hline Services & 7533 & 8422 & 8066 & 7816 & 7280 \\
Electricity, gas and water & 335 & 394 & 285 & 319 & 237 \\
Construction & 176 & 166 & 198 & 176 & 223 \\
Trade & 805 & 810 & 712 & 859 & 638 \\
Hotels and restaurants & 268 & 176 & 128 & 170 & 76 \\
Transportation, warehousing and communications & 954 & 1019 & 996 & 1140 & 963 \\
Financial services & 1321 & 1569 & 1401 & 1141 & 1198 \\
Business services & 3321 & 3898 & 3945 & 3698 & 3622 \\
Education & 102 & 113 & 127 & 71 & 68 \\
Health and social services & 64 & 82 & 60 & 39 & 71 \\
Social and personal service industries & 142 & 164 & 186 & 163 & 150 \\
Other services & 45 & 31 & 28 & 40 & 34 \\
\hline
\end{tabular}

Source: UNCTAD, WIR 2015 
Throughout the observed period, a total of 818 green field projects were implemented in the tourism industry with the largest number of projects implemented in 2010 . A decrease in the number of these projects began this year, registering a fall from 268 in 2010 to 76 in 2014. The largest number of green field projects was implemented in the business service sector amounting to 18.484 projects. The tourism industry assumes the seventh place out of the eleven analyzed industries based on the number of implemented projects.

The value of the implemented green field projects can be seen in Table 8.

Table 8 - Value of green field projects by industries, 2010-2014 (million USD)

\begin{tabular}{lrrrrr}
\hline & \multicolumn{1}{c}{2010} & \multicolumn{1}{c}{2011} & \multicolumn{1}{c}{2012} & \multicolumn{1}{c}{2013} & \multicolumn{1}{c}{2014} \\
\hline Services & 331654 & 355508 & 318019 & 402615 & 340773 \\
Electricity, gas and water & 67990 & 90258 & 65543 & 93638 & 65054 \\
Construction & 36793 & 36426 & 57389 & 38510 & 63257 \\
Trade & 29400 & 25899 & 19426 & 26606 & 23808 \\
Hotels and restaurants & 26684 & 18568 & 13801 & 20815 & 8955 \\
Transportation, warehousing and com- & 52697 & 56445 & 42355 & 65883 & 60522 \\
munications & 43278 & 48577 & 44437 & 36253 & 36073 \\
Financial services & 62587 & 67346 & 58908 & 112268 & 72659 \\
Business services & 1468 & 1618 & 1662 & 864 & 898 \\
Education & 2012 & 1291 & 2040 & 399 & 2331 \\
Health and social services & 6237 & 6309 & 10912 & 6183 & 6611 \\
Social and personal service industries & 2510 & 2773 & 1546 & 1197 & 605 \\
\hline Other services & & & & &
\end{tabular}

Source: UNCTAD (2015)

The value of implemented green field projects in the observed period in the tourism industry has accounted for 88.821 million USD. The largest value of implemented projects was generated in the energy industry and amounted to 382.482 million USD. According to the value of implemented green field projects, the tourism industry is ranked seventh out of the total number of eleven analyzed industries.

\section{Conclusion}

Globalization process has brought about significant changes in all spheres of social, political and economic life. Due to the effects of globalization, certain changes can be observed in the world economy, primarily in liberalization of international trade, free movement of capital, workforce and goods, as well as provision of services, breaking down the barriers that were on the way of these changes. Tourism is among those industries that can be considered increasingly important for the global economy, in particular mass tourism. We can also conclude that the process of globalization, new technologies 
and the Internet have triggered changes in the field of transport and communications and they exerted a considerable impact on the overall tourism development. This influence can be observed in the constant rise of tourist trips and tourists, as well as continuously rising revenues in the tourism industry with an incessant reduction of costs. It can be concluded that the globalization processes, which have altered the global economy, especially tourism-related industries, have greatly affected tourism development, principally mass tourism. The development and progress of tourism have also produced certain changes, which exert a strong impact on tourism-related industries. In that sense, the view of tourism as an outcome of economic development has evolved based on a great number of studies to a new view of tourism as a factor of economic development. Such conclusion is grounded on the fact that tourism cross - connects certain industries, so that their interdependence becomes greater, as well as their dependence on tourism development. The economic tourism activity has direct and indirect effects on the overall economic development, which is increasingly evident through time and thus the fact that tourism influences economic development and not vice versa can no longer be overlooked. The growth rates manifest direct and total effects of T \& T on GDP and qualify tourism industry in those activities to grow faster than GDP growth at the global level. This shows that this industry may be the solution to combating adverse effects of the global economic crisis and it is increasingly becoming a factor of development of the world economy, exerting more significant impact on GDP growth. Nominal values measured by the earned value, and development of measured growth rates make this industry increasingly important and must be seriously considered in the future, especially concerning the tertiary sector of the economy, where we should not neglect the impact of these activities on the secondary industry sector as a significant factor in GDP growth. The positive impact of $T \& T$ employment is apparent, and it is measured both by the number of employees and employment growth rates. These indicators clearly point to the employment growth rates in $\mathrm{T} \& \mathrm{~T}$ and the growing impact of employment on a global scale. The number of employees observed through a total impact of tourism (direct, indirect and induced) indicates that this industry has a more significant impact concerning this economic indicator. Constantly growing participation in the overall number of employees indicates that a positive trend should certainly continue in the future. Foreign direct investment is an important factor of tourism development dynamics, especially in developing countries. However, there are many methodological problems of quantifying the effects of FDI on tourism development in this field, and new models are being proposed to overcome such an issue. So far, the accepted models used to define the quantification of the effects of FDI on tourism development include: the TSI model and "Oli" model. When it comes to investments, measurement of the abovementioned models is unequivocally proven by concluding that the investments in $T$ \& $T$ are constantly growing both in nominal terms and in terms of progress measured by growth rates. These indicators point to the strong impact of investments in $T \& T$ activities, particularly in the field of measuring the total impact of the TSA model, and thus, it can be concluded that this activity is not only increasingly important investment destination, but it has become an increasingly attractive investment destination for investors because it shows the current economic conditions, solid stability and capacity for further investment. According to the UNCTAD classification, there are eleven service industries in the statistical database. Tourism is ranked seventh by the number and value of green field projects. 


\section{Bibliography}

[1] Bošković, T. (2009). Turizam kao factor privrednog razvoja. Škola biznisa, 2, 23-28.;

[2] Holowiecka B., Grzelak-Kostulska E., Kwatkowski G.,(2011), Impact of Globalization on Tourist Preferences and Activiti, U: In the scale of globalization. Think Globalli, Change Individualy in the 21 st. Century, 2011, (55-62), Ostrava: University of Ostrava;

[3] Marin-Pantelescu, A., \& State, O. (2008). The consequences of globalization upon "safe" tourism. Academica Tusistica, 1(2), 8-14.

[4] Nedeljković, O., Jovanović, R., \& Đokić, M. (2013). Trendovi razvoja i uticaj globalizacije na turizam. Časopis za ekonomiju i tržišne komunikacije, 5(1), 73-86. doi: 10.7251/EMC1301073N

[5] UNCTAD, (2007), FDI in Tourism: The Development Dimension, New York and Geneva: United Nations;

[6] United Nations, 2008, Tourism Satelite Account: Recommended Methodological Framework, Statistic Division, New York.

[7] UNCTAD, (2010), Promoting Foreign Investment in Tourism, New York and Geneva: United Nations.

[8] World Travel \& Tourism Council, 2015: Travel \& Tourism-Economic Impact 2015, World, annual Report, London.

[9] UNCTAD, (2015), World Investment Report, New York and Geneva: United Nations.

[10] Vukadinović P., Knežević G., Mizdraković V., Globalizacija i strane direktne investicije u Srbiji, U: Globalizacija i savremeno poslovanje, 20.12.2013, (57-64), Bijeljina BiH: Univerzitet Sinergija.

[11] http://enugustatetourismboard.com, visited 06.08.2015. 